\title{
UPAYA MENINGKATKAN SIKAP ILMIAH DAN HASIL BELAJAR BAHASA INDONESIA DENGAN MENGGUNAKAN PENDEKATAN ACCELERATED LEARNING TYPE MASTER DI KELAS V MI 27/E3 KERINCI
}

\author{
Hidayati \\ MI 27/E3 Kerinci \\ e-mail: atihidayati8@gmail.com
}

\begin{abstract}
ABSTRAK
Penelitian ini dilatar belakangi oleh sikap ilmiah murid dengan kategori rendah sehingga mengakibatkan rendahnya hasil belajar murid kelas I MI 27/E3 Kerinci, yang disebabkan oleh proses pembelajaran di kelas tersebut berjalan lamban karena kurangnya kemampuan murid dalam menyerap serta memahami informasi baru, dan sulit mempertahankan informasi yang sudah didapat. Untuk mengatasi masalah tersebut, dilakukan upaya dengan menggunakan pendekatan Accelerated Learning yang dapat menghasilkan penyerapan informasi dan pemahaman yang lebih baik.

Penelitian ini merupakan penelitian tindakan kelas (classroom action research) yang bertujuan untuk mengetahui peningkatan sikap ilmiah dan hasil belajar Bahasa Indonesia murid. Penelitian ini dilakukan dalam 3 siklus dengan menggunakan pendekatan Accelerated Learning. Subjek penelitian ini adalah murid kelas I MI 27/E3 Kerinci, dengan jumlah murid 22 orang. Waktu pelaksanaan semester I tahun ajaran 2019/2020.Teknik yang digunakan dalam pengumpulan data adalah lembar observasi, dan evaluasi.

Berdasarkan hasil penelitian ini menunjukkan adanya peningkatan sikap ilmiah dan hasil belajar bahasa Indonesia murid pada tiap siklus. Peningkatan sikap ilmiah murid terlihat dari rata-rata persentase sikap ilmiah murid pada tiap siklusnya, di siklus I rata-rata persentase sikap ilmiah murid sebesar 62,2\%, di siklus II meningkat menjadi 71,8\%, di siklus III mencapai 81,3\%. Selain sikap ilmiah, rata-rata hasil belajar Bahasa Indonesia murid dan jumlah murid yang tuntas juga meningkat pada setiap siklusnya, siklus I nilai rata-rata murid sebesar 63,64 dengan jumlah murid yang tuntas sebanyak 7 orang, meningkat pada siklus II menjadi 70,45 nilai rata-rata murid dengan jumlah murid yang tuntas sebanyak 10 orang, dan meningkat lagi pada siklus III menjadi 83,52 nilai rata-rata murid dengan jumlah murid yang tuntas sebanyak 19 orang.
\end{abstract}

Berdasarkan hasil penelitian ini menunjukkan bahawa pendekatan accelerated learning dapat meningkatkan sikap ilmiah dan hasil belajar Bahasa Indonesia murid di kelas I MI 27/E3 Kerinci.

Kata Kunci : Pendekatan Accelerated Learning, Sikap Ilmiah, dan Hasil Belajar Bahasa Indonesia 


\section{PENDAHULUAN}

Proses pembelajaran merupakan suatu kegiatan yang diciptakan dengan sengaja, bertujuan untuk merubah perilaku anak. Perubahan perilaku di sini adalah peubahan dari kondisi prexisting condition yang berupa pengetahuan yang ada sebelum bertemu pengalaman menjadi existing condition yang berupa pengetahuan yang ada setelah bertemu pengalaman. Beberapa orang menyamakan arti dari mendidik dan mengajar, sebenarnya kedua kata tersebut memiliki makna yang berbeda. Dalam mendidik hanya menitik beratkan kepada peningkatan kedewasaan seseorang, sementara mengajar menitik beratkan kepada peningkatan kemampuan otak (intelejensi).

Peningkatan hasil belajar murid sangat dipengaruhi oleh kualitas guru dalam mengajar, hasil belajar yang maksimal dapat diperoleh dari pemilihan strategi dan pendekatan yang tepat. Tidak hanya mampu memilih namun seorang guru juga dituntut mampu menguasi strategi dan pendekatan yang sesuai dengan karakter murid untuk memperoleh hasil yang maksimal.

Proses pembelajaran di MI 27/E3 Kerinci telah divariasikan metode belajarnya, tidak hanya terpaku kepada metode ceramah.Yang menjadi masalah adalah masih terdapat beberapa kelas yang memiliki nilai rata-rata di bawah standar kurikulum yaitu 67. Nilai rata-rata ujian MID semester 1 murid kelas I MI 27/E3 Kerinci tahun ajaran 2018/2019 dapat dilihat pada tabel berikut ini :

Tabel 1.1. Rata-Rata Nilai Ujian Mid Semester 1 Kelas I MI 27/E3 Kerinci

\begin{tabular}{|c|c|}
\hline Mata Pelajaran & Rata-rata \\
\hline Pendidikan Agama & 73,50 \\
Pendidikan Kewarganegaraan & 73,50 \\
Pendidikan Jasmani & 75,00 \\
Bahasa Indonesia & 65,50 \\
\hline
\end{tabular}

Sumber : Data Ujian Mid Semester Kelas I MI27/E3 Kerinci

Dari tabel di atas jelas terlihat perbedaan antara nilai mata pelajaran bahasa Indonesia dengan mata pelajaran lainnya. Yang menyebabkan rendahnya nilai mata pelajaran bahasa Indonesia adalah karena dalam proses pembelajaran murid di kelas yang lamban. Hal ini diakibatkan oleh kurangnya kemampuan murid dalam menyerap serta memahami informasi baru, dan sulit mempertahankan informasi yang sudah didapat. Hal ini didasari oleh sikap ilmiah murid dengan kategori rendah, dilihat dari kurangnya keberanian murid dalam bertanya, 
kurangnya keinginan murid mencatat hal-hal penting yang diberikan oleh guru, dan kurangnya keberanian murid dalam mengajukan pendapat.

Untuk itulah, disamping dibekali dengan ilmu pengetahuan, sudah seharusnya murid memiliki kemampuan yang adaptif untuk mengatasi perubahan dengan mengatur sikap ilmiah pada dirinya dan belajar memecahkan masalah sejak dini. Accelerated Learning adalah pendekatan pembelajaran yang bertujuan untuk menggugah sepenuhnya kemampuan belajar para murid sehingga membuat belajar menyenangkan dan memuaskan yang memberikan sumbangan sepenuhnya pada kebahagiaan, kecerdasan, kompetensi dan keberhasilan.

\section{METODE PENELITIAN}

\section{Rancangan Penelitian}

Penelitian yang digunakan adalah jenis penelitian tindakan kelas (PTK) yaitu penelitian reflektif yang dilakukan oleh pendidik sendiri terhadap kurikulum, pengembangan sekolah, meningkatkan prestasi belajar, pengembangan keahlian mengajar, dan sebagainya dengan tujuan memperbaiki mutu praktik pembelajaran dalam suatu siklus. Menurut Iskandar (2009), "Penelitian tindakan kelas merupakan bagian dari penelitian tindakan (action research) yang dilakukan oleh guru dan dosen di kelas (sekolah dan perguruan tinggi) tempat ia mengajar yang bertujuan untuk memperbaiki dan meningkatkan kualitas dan kuantitas proses pembelajaran di kelas".

Penelitian ini dilaksanakan dalam beberapa siklus berulang. Tahap-tahap penelitan yang dimaksud adalah sebagai berikut :

1. Perencanaan (planing)

Perencanaan tindakan merupakan yang menjelaskan apa, mengapa, kapan, di mana, oleh siapa, dan bagaimana tindakan itu dilakukan.

2. Tindakan (acting)

Tindakan merupakan pelaksanaan atas seluruh rencana yang telah dibuat sebelumnya.

3. Observasi (observing)

Observasi dilakukan bersamaan dengan tindakan, dimana pada observasi ini data-data dikumpulkan. Data yang dikumpulkan yaitu tentang tindakan yang terlaksana dan perencanaan tindakan yang telah dibuat, serta dampaknya terhadap proses dan hasil 
intruksional yang dikumpulkan dengan alat bantu instrumen pengamatan yang dikembangkan oleh peneliti.

\section{Refleksi (reflecting)}

Tahapan refleksi ini merupan tahapan untuk mengkaji dan memproses data yang didapat saat melakukan pengamatan/observasi tindakan.

Hasil belajar murid dapat dilihat dari hasil tes kemampuan kognitif murid menggunakan soal-soal objektif pada tes akhir di akhir siklus. Alasan digunakan soal berbentuk objektif adalah untuk menghindari masuknya unsur subjektivitas (unsur pribadi yang masuk mempengaruhi nilai) diri penilai.

Tes yang digunakan dalam penelitian ini adalah post-test (tes akhir). Tes akhir dilakukan setelah berakhirnya rangkaian pembelajaran pada satu siklus. Agar tes yang digunakan berkualitas, soal tes diuji coba terlebih dahulu, kemudian dilakukan analisis item soal tes. Analisis ini digunakan untuk mengetahui validitas, daya pembeda, indeks kesukaran dan reliabilitas soal tes.

1. Validitas

Suatu tes hasil belajar dapat dikatakan valid apabila materi tes tersebut benar-benar merupakan bahan pelajaran yang diberikan. Validitas adalah keadaan yang menggambarkan tingkat instrumen yang bersangkutan mampu mengukur apa yang akan diukur (Arikunto, 2010). Validitas tes yang dilihat adalah validitas isi yang tinggi jika bahan tes sesuai dengan yang telah diberikan, sesuai dengan kurikullum dan sesuai dengan pengalaman murid.

2. Tingkat kesukaran

Menurut Arikunto (2010) soal yang baik adalah soal yang tidak terlalu mudah dan tidak terlalu sukar. Besarnya indeks kesukaran soal ditentukan dengan rumus:

$$
P=\frac{B}{J S}
$$

Keterangan:

$$
\begin{array}{ll}
\mathrm{P} & =\text { Indeks kesukaran } \\
\mathrm{B} & =\text { Banyak murid yang menjawab soal tersebut dengan benar } \\
\mathrm{JS} & =\text { Jumlah seluruh murid peserta tes }
\end{array}
$$

Untuk mengetahui besarnya indeks kesukaran, kriteria yang digunakan adalah: 


$$
\begin{aligned}
& 0,00 \leq \mathrm{p}<0,30: \text { sukar } \\
& 0,30 \leq \mathrm{p}<0,70: \text { sedang } \\
& 0,70 \leq \mathrm{p} \leq 1,00: \text { mudah }
\end{aligned}
$$

Soal-soal yang dianggap baik yaitu soal-soal dengan kriteria sedang, tetapi perlu diketahui bahwa tidak berarti soal-soal yang terlalu mudah atau sukar sekali tidak boleh digunakan (Arikunto, 2010). Jadi, soal yang digunakan dalam penelitian ini adalah soal dengan kriteria tingkat kesukaran sukar, sedang dan mudah.

3. Daya pembeda

Arikunto (2010) mengemukakan, daya pembeda soal adalah kemampuan suatu soal untuk dapat membedakan antara murid yang pandai (berkemampuan tinggi) dengan murid yang kurang pandai (berkemampuan rendah). Untuk perhitungan kelompok tes dibagi dua sama besar, 50\% kelompok atas dan 50\% kelompok bawah. Daya beda soal dihitung dengan rumus:

$$
D=\frac{B A}{J A}-\frac{B B}{J B}=P_{A}-P_{B}
$$

Keterangan:

D = Indeks diskriminasi atau daya pembeda

JA = Banyak peserta kelompok atas

$\mathrm{JB}=$ Banyak peserta kelompok bawah

BA = Banyak peserta kelompok atas yang menjawab benar

$\mathrm{BB}=$ Banyak peserta kelompok bawah yang menjawab benar

$\mathrm{P}_{\mathrm{A}} \quad=$ Proporsi kelompok atas yang menjawab benar

$\mathrm{P}_{\mathrm{B}} \quad=$ Proporsi kelompok bawah yang menjawab benar

Dengan kriteria nilai D adalah:

$$
\begin{aligned}
& 0,00 \leq \mathrm{D}<0,20: \text { jelek } \\
& 0,20 \leq \mathrm{D}<0,40: \text { cukup } \\
& 0,40 \leq \mathrm{D}<0,70: \text { baik } \\
& 0,70 \leq \mathrm{D} \leq 1,00 \text { : sangat baik }
\end{aligned}
$$

Nilai-nilai D yang memenuhi kriteria yang jelek dibuang dan nilai D yang negatif dibuang (Arikunto, 2010). Soal yang digunakan dalam penelitian ini yaitu soal dengan daya beda cukup dan baik. 


\section{Reliabilitas soal}

Sebuah tes disebut reliabel apabila hasil-hasil tersebut menunjukkan ketepatan (Arikunto, 2010). Untuk menentukan reliabilitas digunakan rumus Kuder Richarson 21 yang disingkat dengan K-R 21, sebagai berikut:

$$
r_{11}=\left(\frac{n}{n-1}\right)\left(1-\frac{M(n-M)}{n S t^{2}}\right) \text { dengan } S t^{2}=\frac{\sum X^{2}-\frac{\left(\sum X\right)}{N}}{N}
$$

Keterangan:

$$
\begin{aligned}
& \mathrm{r}_{11}=\text { Koefisien reliabilitas soal } \\
& \mathrm{St}^{2}=\text { Variansi dari tes } \\
& \mathrm{n}=\text { Banyak item } \\
& \mathrm{X}_{\mathrm{i}}=\text { Skor total butir soal } \\
& \mathrm{N}=\text { Jumlah peserta tes } \\
& \sum X=\text { Jumlah total suara yang benar } \\
& \sum X^{2}=\text { Jumlah kuadrat skor total } \\
& M=\frac{\sum X}{N}=\text { Skor rata-rata }
\end{aligned}
$$

Sebagai kriteria penghitung reliabilitas soal didasarkan pada ketentuan di bawah ini:

$0,00 \leq \mathrm{r}_{11}<0,20$ : reliabilitas sangat rendah

$0,20 \leq \mathrm{r}_{11}<0,40:$ reliabilitas rendah

$0,40 \leq \mathrm{r}_{11}<0,60$ : reliabilitas cukup

$0,60 \leq \mathrm{r}_{11}<0,80:$ reliabilitas tinggi

$0,80 \leq \mathrm{r}_{11} \leq 1,00$ : reliabilitas sangat tinggi

Soal yang digunakan dalam penelitian ini adalah soal yang mempunyai reliabilitas tinggi atau sangat tinggi. Pengambilan data kuantitatif dilakukan dengan menggunakan lembar observasi sikap ilmiah murid. Untuk menghitung persentase sikap ilmiah menggunakan lembar observasi sikap ilmiah digunakan kriteria nilai sebagai berikut :

$$
\begin{aligned}
& 0-25 \%=\text { Sikap ilmiah dengan kategori "kurang" } \\
& 26 \%-50 \%=\text { Sikap ilmiah dengan kategori "cukup" }
\end{aligned}
$$


$51 \%-75 \%=$ Sikap ilmiah dengan kategori "baik"

$76 \%-100 \%=$ Sikap ilmiah dengan kategori "baik sekali"

\section{HASIL DAN PEMBAHASAN}

Gambaran mengenai peningkatan sikap ilmiah murid yang diperoleh dari penerapan dapat dilihat pada tabel berikut ini :

Tabel 4.18 Peningkatan Sikap Ilmiah Murid

\begin{tabular}{|c|l|c|c|c|}
\hline No & \multicolumn{1}{|c|}{ Indikator Sikap yang Diamati } & \multicolumn{3}{c|}{ Persentase } \\
\cline { 3 - 5 } & & Siklus I & Siklus II & Siklus III \\
\hline 1 & Sikap respek terhadap data/fakta & 68,9 & 75,2 & 85,1 \\
2 & Sikap berfikir kritis & 68,1 & 75,6 & 83,7 \\
3 & Sikap penemuan dan kreatifitas & 67,0 & 73,5 & 81,5 \\
4 & Sikap berfikiran terbuka dan kerja sama & 63,1 & 63,1 & 77,8 \\
5 & Sikap ketekunan & 63,9 & 71,8 & 78,6 \\
\hline \multicolumn{2}{|c|}{ Rata-rata } & $\mathbf{6 2 , 2}$ & $\mathbf{7 1 , 8}$ & $\mathbf{8 1 , 3}$ \\
\hline
\end{tabular}

Dari tabel di atas dapat disimpulkan bahwa setiap siklus terdapat peningkatan sikap ilmiah murid yang semakin baik, sehingga dapat disimpulkan bahwa penerapan pendekatan Accelerated Learning dalam proses pembelajaran Bahasa Indonesia dapat meningkatkan sikap ilmiah murid. berikut ini :

Gambaran mengenai peningkatan rata-rata aktivitas belajar murid dapat dilihat pada tabel

Tabel 4.19 Rata-Rata Peningkatan Aktivitas Murid

\begin{tabular}{|c|c|c|c|c|}
\hline \multirow{2}{*}{ No } & Variabel yang diteliti & \multicolumn{3}{|c|}{ Jumlah/Persentase } \\
\cline { 3 - 5 } & & Siklus I & Siklus II & Siklus III \\
\hline 1. & Rata-rata aktivitas belajar murid & 58,35 & 71,48 & 74,97 \\
\hline
\end{tabular}

Dari tabel di atas dapat dilihat rata-rata aktivitas murid dalam proses pembelajaran. Pada pelaksanaan tindakan siklus I rata-rata aktivitas murid masih berada pada kategori cukup aktif, selanjutnya pada siklus II dan III rata-rata aktivitas murid meningkat menjadi aktif.

Gambaran mengenai peningkatan hasil belajar murid dapat dilihat pada tabel berikut ini :

Tabel 4.20 Peningkatan Hasil Belajar Murid Tiap Siklus

\begin{tabular}{|c|l|c|c|c|}
\hline No & \multicolumn{1}{|c|}{ Variabel yang diteliti } & \multicolumn{3}{|c|}{ Jumlah/Persentase } \\
\cline { 3 - 5 } & & Siklus I & Siklus II & Siklus III \\
\hline 1 & Nilai rata-rata murid & 63,64 & 70,45 & 83,52 \\
2 & Jumlah murid yang berhasil pada siklus I & 7 orang & 10 orang & 19 orang \\
3 & Persentase keberhasilan murid & $31,8 \%$ & $45,4 \%$ & $83,4 \%$ \\
4 & Jumlah murid yang belum berhasil pada siklus I & 15 orang & 12 orang & 3 orang \\
5 & Persentase murid yang belum berhasil & $68,2 \%$ & $54,6 \%$ & $16,6 \%$ \\
\hline
\end{tabular}

Dari tabel di atas dapat disimpulkan bahwa hasil belajar murid pada setiap siklus semakin membaik. Jadi, dapat disimpulkan bahwa penerapan pendekatan Accelerated Learning pada mata 
pelajaran Bahasa Indonesia dapat meningkatkan hasil belajar murid. Secara umum, peningkatan sikap ilmiah, aktivitas, dan hasil belajar murid dapat dilihat pada gambar 4.1 di bawah ini :

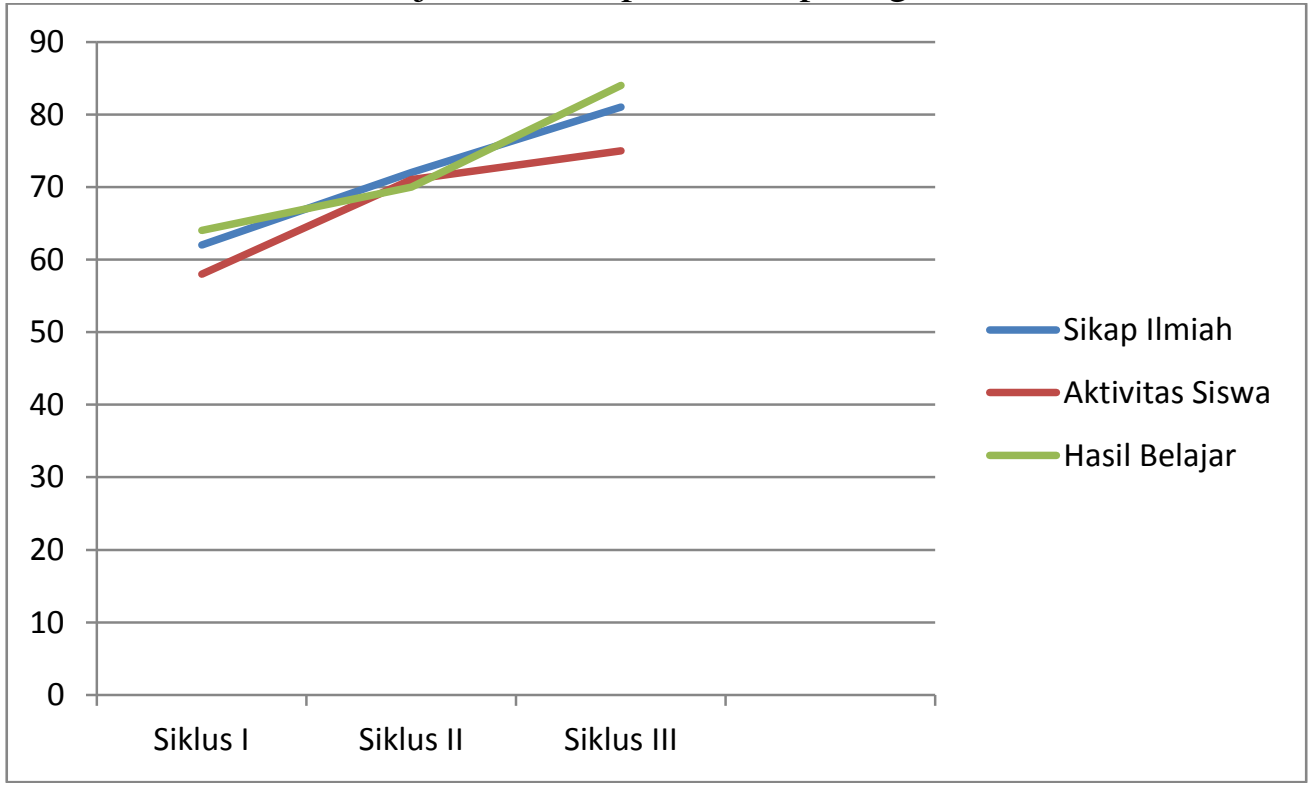

Gambar 4.1 Peningkatan Sikap Ilmiah, Aktivitas, dan Hasil Belajar Murid

Gambaran mengenai peningkatan sikap ilmiah murid pada setiap siklus dapat dilihat pada tabel berikut ini :

Tabel 4.21 Gambaran Peningkatan Sikap Ilmiah Murid Setiap Siklus

\begin{tabular}{|c|c|c|c|c|c|c|c|c|c|c|c|c|c|}
\hline \multirow[t]{2}{*}{ No } & \multirow[t]{2}{*}{ Aspek-aspek Sikap yang Dinilai } & \multicolumn{4}{|c|}{ Siklus I } & \multicolumn{4}{|c|}{ Siklus II } & \multicolumn{4}{|c|}{ Siklus III } \\
\hline & & 1 & 2 & 3 & 4 & $\mathbf{1}$ & 2 & 3 & 4 & $\mathbf{1}$ & 2 & 3 & 4 \\
\hline & Sikap respek terhadap data/fakta & & & & & & & & & & & & \\
\hline 1 & Objektif/jujur & & $\sqrt{ }$ & & & & & $\sqrt{ }$ & & & & & \\
\hline 2 & Tidak memanipulasi data & & $\sqrt{ }$ & & & & & $\sqrt{ }$ & & & & & \\
\hline 3 & Tidak purbasangka & & $\sqrt{ }$ & & & & & $\sqrt{ }$ & & & & & \\
\hline 4 & Mengambil keputusan sesuai fakta & & $\sqrt{ }$ & & & & & $\sqrt{ }$ & & & & & $\sqrt{ }$ \\
\hline 5 & $\begin{array}{l}\text { Tidak bercampur fakta dengan } \\
\text { pendapat }\end{array}$ & & $\sqrt{ }$ & & & & & $\sqrt{ }$ & & & & $\sqrt{ }$ & \\
\hline & Sikap berfikir kritis & & & & & & & & & & & & \\
\hline 6 & Meragukan temuan teman & & $\sqrt{ }$ & & & & & $\sqrt{ }$ & & & & $\sqrt{ }$ & \\
\hline 7 & Menanyakan setiap perubahan/hal baru & & $\sqrt{ }$ & & & & & $\sqrt{ }$ & & & & & \\
\hline 8 & Mengulangi kegiatan yang dilakukan & & $\sqrt{ }$ & & & & & $\sqrt{ }$ & & & & & \\
\hline 9 & $\begin{array}{l}\text { Tidak mengabaikan data meskipun } \\
\text { kecil }\end{array}$ & & $\sqrt{ }$ & & & & & $\sqrt{ }$ & & & & & \\
\hline 10 & $\begin{array}{l}\text { Mencari kebenaran untuk suatu } \\
\text { kesimpulan }\end{array}$ & & $\sqrt{ }$ & & & & & $\sqrt{ }$ & & & & & $\sqrt{ }$ \\
\hline 11 & $\begin{array}{l}\text { Sikap penemuan dan kreatifitas } \\
\text { Menggunakan dakta untuk dasar } \\
\text { konklusi }\end{array}$ & $\sqrt{ }$ & & & & & $\sqrt{ }$ & & & & & $\sqrt{ }$ & \\
\hline
\end{tabular}

Jurnal Edu Research

Indonesian Institute For Corporate Learning And Studies (IICLS) 


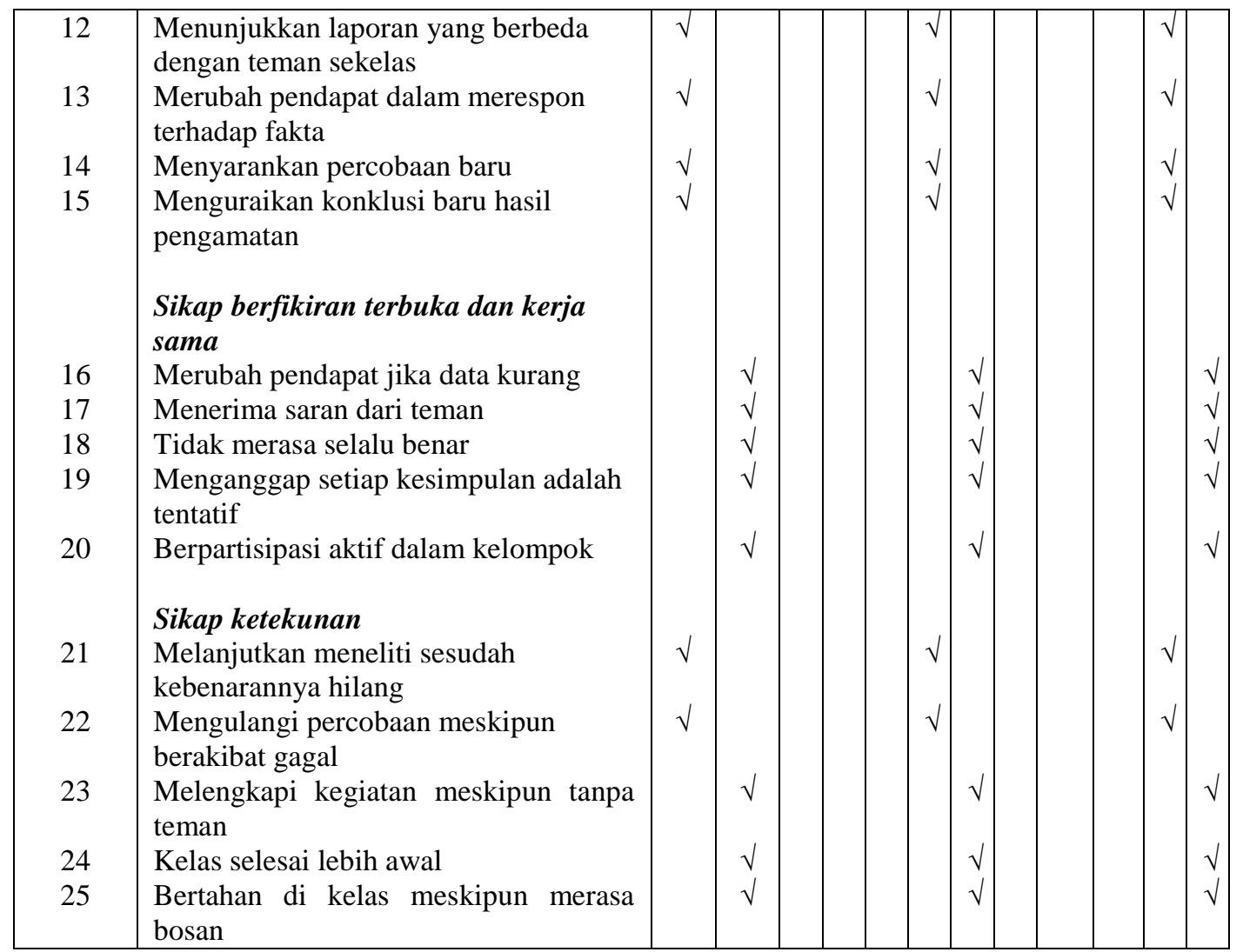

Tabel di atas menunjukkan bahwa terjadinya peningkatan sikap ilmiah murid pada setiap siklus berdasarkan pengamatan oleh observator yaitu guru mata pelajaran Bahasa Indonesia Kelas I MI27/E3 Kerinci..

Gambaran mengenai peningkatan aktivitas murid pada setiap siklus dapat dilihat pada tabel berikut ini :

Tabel 4.22 Gambaran Peningkatan Aktivitas Murid Setiap Siklus

\begin{tabular}{|c|c|c|c|c|c|c|c|}
\hline \multirow[t]{2}{*}{ No } & \multirow[t]{2}{*}{ Aktivitas yang Diamati } & \multicolumn{2}{|c|}{ Siklus I } & \multicolumn{2}{|c|}{ Siklus II } & \multicolumn{2}{|c|}{ Siklus III } \\
\hline & & Jlh & $\%$ & Jlh & $\%$ & Jlh & $\%$ \\
\hline 1 & Pendahuluan & 19 & 86,3 & 21 & 95,4 & 22 & 100 \\
\hline 2 & $\begin{array}{l}\text { Muridyang melakukan do'a bersama } \\
\text { murid }\end{array}$ & 19 & 68,3 & 21 & 95,4 & 22 & 100 \\
\hline 3 & Murid yang hadir & 22 & 100 & 22 & 100 & 22 & 100 \\
\hline 4 & $\begin{array}{l}\text { Murid yang mempersiapkan persiapan } \\
\text { pembelajaran, mempersiapkan buku } \\
\text { paket dan alat yang mendukung } \\
\text { lainnya }\end{array}$ & 22 & 100 & 22 & 100 & 22 & 100 \\
\hline 5 & $\begin{array}{l}\text { Murid yang memperhatikan } \\
\text { penyampaikan tujuan pembelajaran }\end{array}$ & 10 & 45,4 & 12 & 54,5 & 18 & 81,8 \\
\hline
\end{tabular}




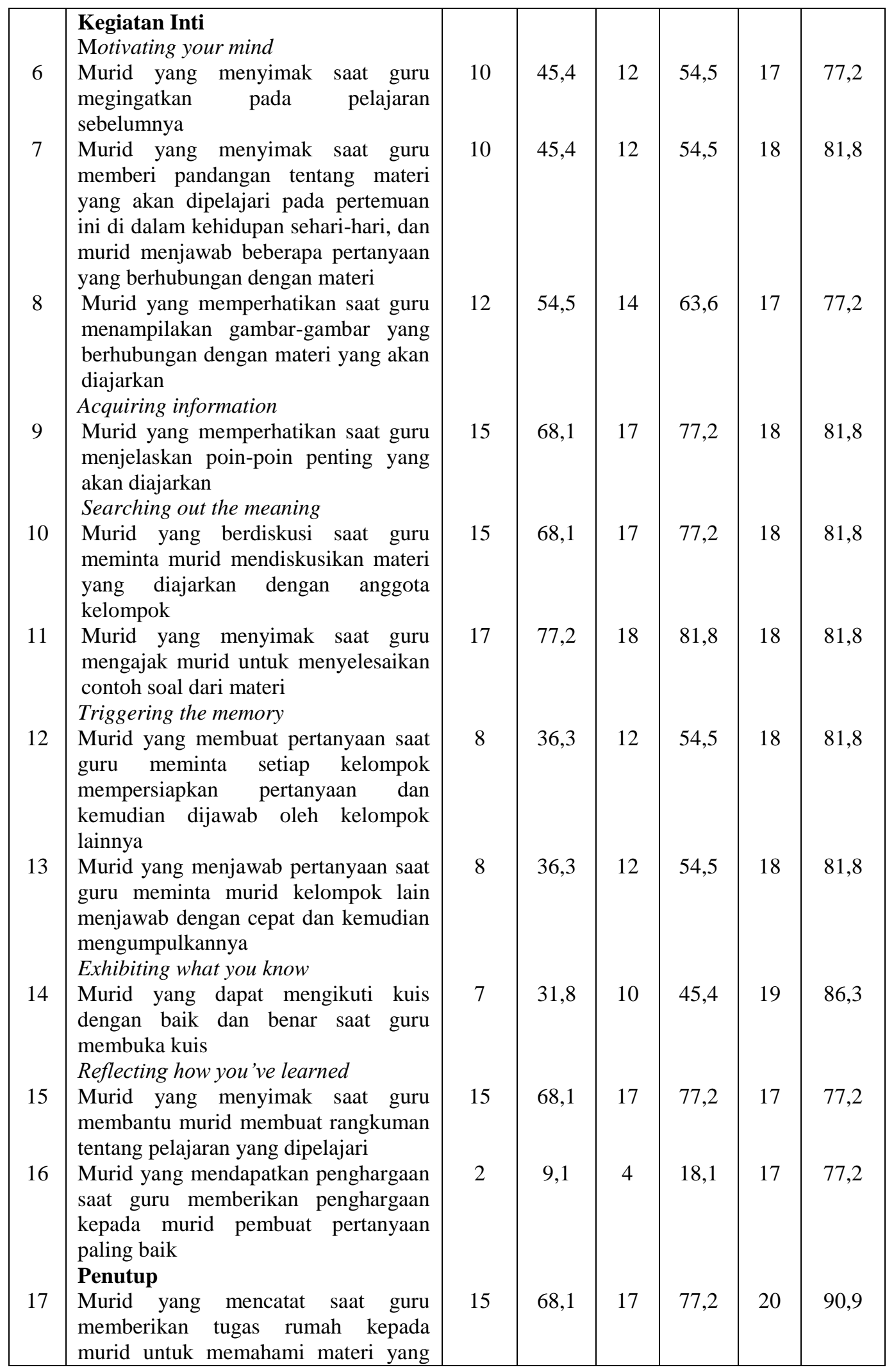




\begin{tabular}{|c|l|c|c|c|c|c|c|}
\hline 18 & $\begin{array}{l}\text { telah dipelajari } \\
\text { Murid yang memperhatikan saat guru } \\
\text { menyampaikan kepada murid untuk } \\
\text { mempelajari, mencari dan menambah } \\
\text { wawasan tentang materi berikutnya }\end{array}$ & 15 & 68,1 & 17 & 77,2 & 20 & 90,9 \\
$\begin{array}{l}\text { Murid yang menjawab salam saat guru } \\
\text { menutup pelajaran dengan } \\
\text { mengucapkan salam. }\end{array}$ & 22 & 100 & 22 & 100 & 22 & 100 \\
\hline Jumlah & $\mathbf{2 6 3}$ & $\mathbf{5 8 , 3 5}$ & $\mathbf{2 9 9}$ & $\mathbf{7 1 , 4 8}$ & $\mathbf{3 6 3}$ & $\mathbf{7 4 , 9 7}$ \\
\hline
\end{tabular}

Tabel di atas menunjukkan terjadinya peningkatan aktivitas belajar murid pada setiap siklus yang diamati oleh observator yaitu guru mata pelajaran Bahasa Indonesia Kelas I MI27/E3 Kerinci.

\section{KESIMPULAN}

Berdasarkan hasil penelitian tindakan kelas yang telah dilaksanakan, dapat disimpulkan bahwa pembelajaran dengan menggunakan pendekatan pembelajaran Accelerated Learning dapat meningkatkan sikap ilmiah dan hasil belajar Bahasa Indonesia murid di Kelas I MI27/E3 Kerinci.

Hal ini dapat dilihat dari rata-rata persentase sikap ilmiah murid pada siklus I sebesar $62,2 \%$, meningkat pada siklus II mencapai 71,8\% dan meningkat lagi pada siklus III mencapai $81,3 \%$. Sedangkan hasil belajar murid pada siklus I sebesar 63,64 jumlah murid yang berhasil sebanyak 7 orang dengan persentase keberhasilan $31,8 \%$, pada siklus II meningkat menjadi 70,45 jumlah murid yang berhasil sebanyak 10 orang dengan persentase keberhasilan 45,4\%, dan meningkat lagi pada siklus III mencapai 83,52 jumlah murid yang berhasil sebanyak 19 orang, dengan persentase keberhasilan $85,4 \%$. Kemudian amati juga aktivitas belajar murid, sama halnya dengan sikap ilmiah dan hasil belajar murid, aktivitas belajar murid juga mengalami peningkatan dimana pada siklus I aktivitas belajar murid sebesar 58,35\%, meningkat pada siklus II menjadi 71,48\%, dan meningkat lagi pada siklus III mencapai 74,97\%.

\section{UCAPAN TERIMA KASIH}

Ucapan terima kasih kepada Kepala Sekolah, tata usaha dan majelis guru MI 27/E3 Kerinci yang telah memotivasi penulis sampai terbitnya jurnal ini.

\section{DAFTAR PUSTAKA}

Ali, 1985. Penelitian Kependidikan Prosedur dan Strategi. Bandung : Angkasa Bandung.

Ali, 2012. Rangkuman Bahasa Indonesia SMA/MA Kelas X, XI, XII. Jakarta : Kompas Gramedia. Arikunto, S. 2010. ManajemenPenelitian. Jakarta: RinekaCipta.

Azhar, 2002. Media Pembelajaran. Jakarta : Raja Grafindo Persada.

Azmi, 2007. Accelerated Learning dan Inplementasinya di Indonesia. Malang : Universitas Wisnuwardana

Azwar, 2013. Sikap Manusia. Yogyakarta : Pustaka Pelajar

Bambang dkk, 2008. Pedoman Penulisan Skripsi. Jambi : Universitas Jambi.

Jurnal Edu Research

Indonesian Institute For Corporate Learning And Studies (IICLS) 
Butar, 2011. Efektivitas Accelerated Learning Model MASTER terhadap hasil belajar murid pada sub materi pokok sistem reproduksi pada manusia kelas XI IPA SMA Negeri 1 Lumban Julu Kabupaten Toba Samosir T.A 2009/2010. Medan : Universitas Negeri Medan

Desi, 2012. Pengaruh Penerapan Accelerated Learning Terhadap Hasil Belajar Biologi Murid Kelas Xi Sma Negeri 4 Surakarta Tahun Pelajaran 2011/2012. Surakarta : Universitas Sebelas Maret

Esther, 2013. Penerapan Pendekatan Accelerated Learning Type SAVI Untuk Meningkatkan Motivasi dan Hasil Belajar. Yogyakarta : UNY

Halliday dkk, 1985. Bahasa Indonesia Jilid I. Jakarta: Erlangga

Hamalik, 2001. Proses Belajar Mengajar. Jakarta : Bumi Aksara

Herson, 2009. Penilaian Sikap Ilmiah dalam Pembelajaran Sains. Jurnal Pelangi Ilmu Iskandar, 2009. Penelitian Tindakan Kelas. Ciputat: Gaung Persada (GP).

Karhami, 1998. Panduan Pembelajaran Bahasa Indonesia SLTP. Jakarta : Depdikbud

Kusaeri, 2013. Prinsip Pokok Accelerated Learning. http://www.trustco.or.id/berita-86performance-management-indoor-training.html (diakses 11 Desember 2013).

Langrehr, 2006. Kemampuan Berfikir Kritis dan Kreatif Matematik. Bandung : UPI

Lou, 2011. The Accelerated Learning Fieldbook. Bandung : Nusa Media.

Nasution, 2006. Kurikulum dan Pengajaran. Jakarta : Bumi Aksara

Ngiza, 2012. Peningkatan Sikap Ilmiah dan Ketuntasan Hasil Belajar Bahasa Indonesia Menggunakan Pendekatan Accelerated Learning Melalui Metode Eksperimen di Kelas VII E SMP Negeri 3 Silo tahun 2012/2013. Kalimantan : Universitas Jember.

Nurkancana, 1986. Evaluasi Pendidikan. Surabaya : Usaha Nasional

Pasaribu, dkk, 1983. Proses Belajar Mengajar. Bandung : Tarsito

Purwako dkk, 2010. Bahasa Indonesia 1 SMA Kelas X. Jakarta: Yudhistita

Putra, 2010. Pengaruh Sikap Ilmiah Murid Terhadap Hasil Belajar Matematika Kelas XII IPA SMA N 9 Kota Jambi Tahun Ajaran 2010/2011. Jambi : Universitas Jambi

Rose, dkk, 2003. Accelerated Learning For $2 i^{\text {st }}$ century. Cara Belajar Cepat Abad XXI. Bandung : Nuansa Cendikia.

Sears dkk, 2004. Bahasa IndonesiaUniversitasJilid 2. Jakarta: Erlangga.

Sudjana. 2005. MetodaStatistika. Bandung: Tarsito.

Sugiyono, 2013. Metode Penelitian Pendidikan. Bandung : Alfabeta.

Wahidmurni, dkk, 2010. Evaluasi Pembelajaran Kompetensi dan Praktik. Yogyakarta : Nuha Litera. 